Completed in December 2007, the

PV system at Nellis Air Force Base

in Nevada is the largest in North

America, capable of producing 14

megawatts. The PV array supplies

Nellis with more than 30 million

kilowatt-hours of electricity a

year, providing more than $25 \%$ of

the total power used by roughly

12,000 people on base.

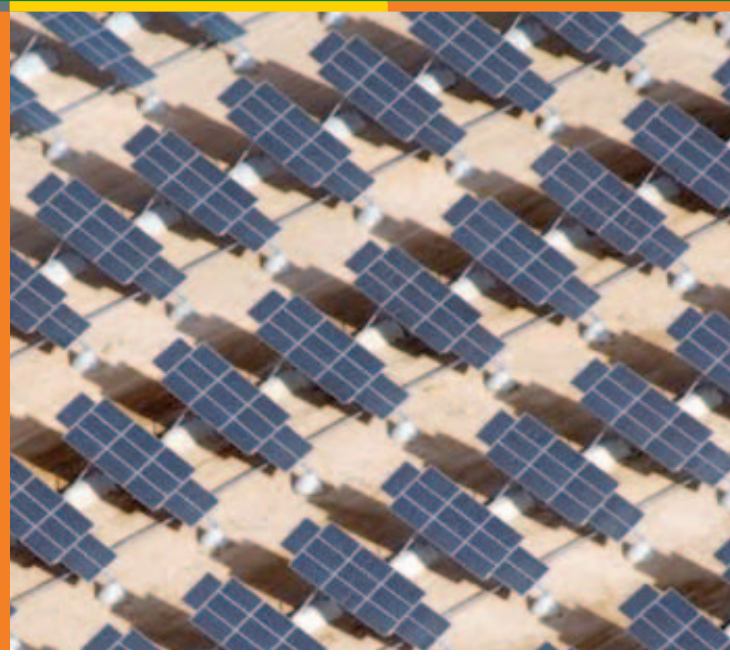

\section{Solar: A Clean Energy Source for Utilities}

Utilities across the country are offering solar electricity to their customers as a viable source of clean energy. To continue accelerating the adoption of solar energy, the U.S. Department of Energy (DOE) Solar Energy Technologies Program (SETP) collaborates with utilities to remove the technical, regulatory, and market challenges they face in deploying solar technologies.

Through targeted activities, each of SETP's four subprograms is addressing these barriers.

\section{Photovoltaics}

The widespread use of solar energy as a clean, carbon-free, cost-effective electricity source will occur through the development of a variety of photovoltaic (PV) technologies. These technologies will meet the diverse requirements of various market segments, focusing on residential and commercial markets for distributed systems as well as utility-scale markets for centralized systems.

To meet these requirements, SETP is investing in approaches across the development pipeline - from basic cell technologies to manufacturing scaleup to total system development. These efforts are focused on minimizing effective life-cycle system cost to allow direct comparison to, and competition with, conventional utility-grid electricity prices.

Although electricity from PV systems is still more expensive than electricity from the utility grid, features such as its diversity and adaptability make PV systems attractive to a range of energy users.

\section{Concentrating Solar Power}

Concentrating solar power (CSP) is a reliable and well-known form of solar power. SETP is ramping up its CSP research, development, and deployment efforts in the following areas: linear concentrator systems, power tower systems, dish/engine systems, thermal storage, and advanced components and systems.

The goals include increasing the use of CSP in the United States, making CSP competitive in the intermediate power market by 2015 , and developing advanced technologies that will reduce systems and storage costs, enabling CSP to be competitive in the baseload power market by 2020. SETP plans to achieve these goals through cost-shared contracts with industry, advanced research at its national laboratories, and working with other government agencies and utilities to remove barriers to the deployment of the technology.

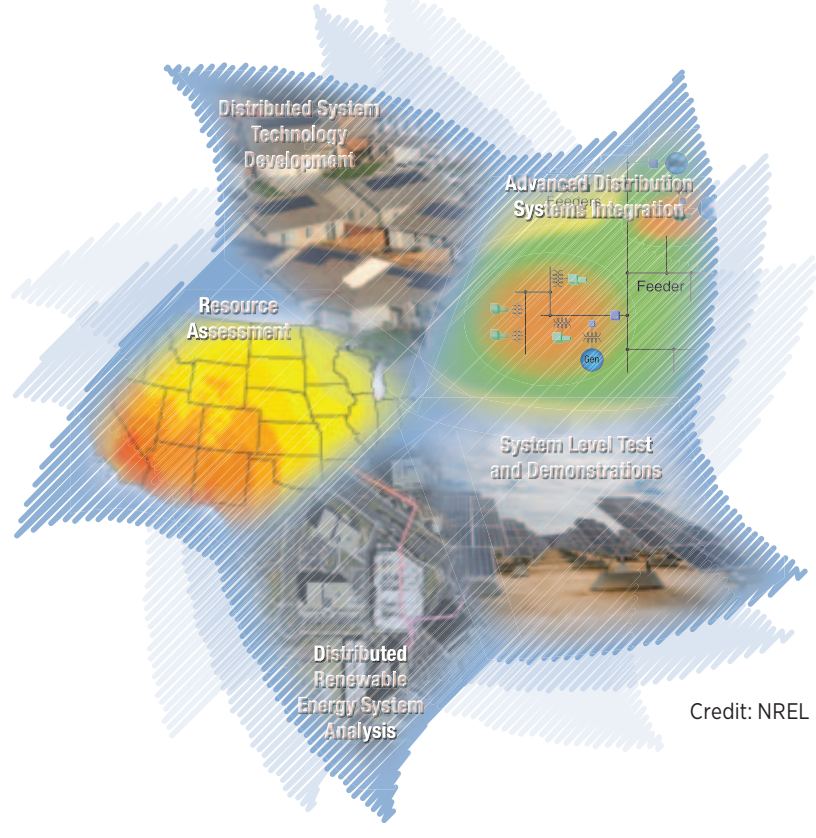

The Systems Integration subprogram focuses on these R\&D areas. 


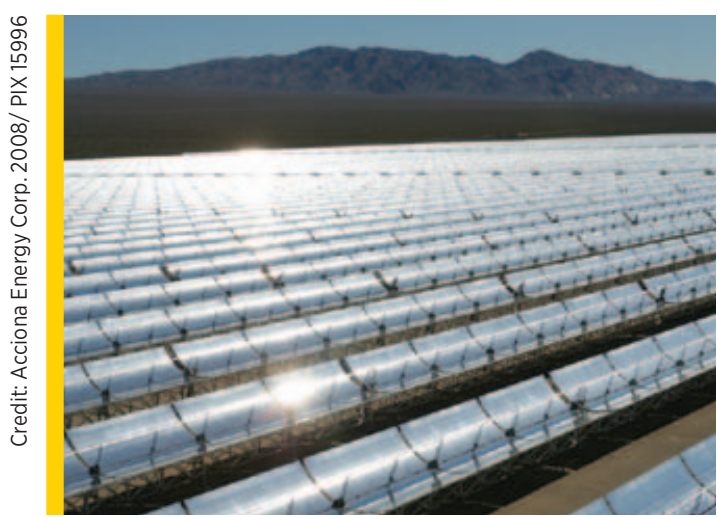

Nevada Solar One, near Boulder City, Nevada, is the third-largest CSP plant in the world with 64 megawatts of capacity. Completed in June 2007, the plant can produce enough electricity to power more than 14,000 homes annually.

\section{Systems Integration}

To seamlessly integrate solar technologies into the nation's electric power grid, it will require new ways of thinking about how we generate and distribute electricity and new technologies that make it simple, safe, and reliable for solar electricity to feed into the grid.

Breaking down the regulatory, technical, and economic barriers to integrating solar electricity into the electric grid is a priority for SETP, especially since specific barriers to the proliferation of distributed solar electric systems vary from place to place.

Instituting net metering rules and simple, consistent interconnection standards is critical to developing solar markets. Technology and equipment (e.g., advanced inverter and controllers) that allow real-time monitoring of the output of the solar system will also benefit both owners and utilities.

Historically, interconnection standards have applied largely to centralized power plants, and the requirements of connecting many small generators to the grid are significantly different. Interconnection standards that make this process easy, inexpensive, and safe are an important part of growing a healthy solar industry.
Other key technical issues being addressed are improving transmission and distribution systems to accommodate two-way power flows and the varying nature of solar power generation.

\section{Market Transformation}

Solar technology research and development $(R \& D)$ is a key activity, but it is equally important to address non-R\&D issues and market barriers to solar. The market transformation activities are designed to facilitate the commercialization of solar technologies by identifying and addressing significant non-R\&D barriers. SETP is actively engaging key stakeholders and early adopters through diverse activities that include education on key issues, policy analysis, and technical assistance.

The following market barriers are being addressed:

- Inconsistent or ineffective interconnection standards, net metering regulations, and utility rate structures.

- Complex and expensive solar installation permitting procedures.

- Lack of flexible, well-proven financing mechanisms for solar projects.

- Limited education and experience among building trade groups.

- Environmental concerns.

- Access to transmission.

In addition, through strategic partnerships with national organizations, SETP provides technical, policy, and market information on solar technologies to state and utility decision makers to assist the growth of centralized solar power systems.

\section{Top 10 Utilities by Solar Megawatts Installed}

On May 28, 2009, the Solar Electric Power Association released its "2008 Top Ten Utility Solar Integration Rankings" report, which lists the utilities that installed the most solar power.

\begin{tabular}{|l|c|}
\hline \multicolumn{1}{|c|}{ Utilities } & $\begin{array}{c}\text { Solar Power } \\
\text { Megawatts (MW) }\end{array}$ \\
\hline (1) Pacific Gas \& Electric Company (San Francisco, California) & 84.9 \\
\hline (2) Southern California Edison (Rosemead, California) & 32.4 \\
\hline (3) San Diego Gas \& Electric (San Diego, California) & 16 \\
\hline (4) Public Service Company of Colorado (Denver, Colorado) & 14.2 \\
\hline (5) Public Service Electric \& Gas Company (Newark, New Jersey) & 5.5 \\
\hline 6 Arizona Public Service Company (Phoenix, Arizona) & 3.56 \\
\hline (7) Hawaiian Electric Company (Honolulu, Hawaii) & 3.54 \\
\hline (8) Portland General Electric in Oregon (Portland, Oregon) & 3.538 \\
\hline (9) Sacramento Municipal Utility District (Sacramento, California) & 2.9 \\
\hline (10 Long Island Power Authority of New York (Uniondale, New York) & 2.5 \\
\hline
\end{tabular}

Prepared by the National Renewable Energy Laboratory (NREL)

NREL is a national laboratory of the U.S. Department of Energy

Office of Energy Efficiency and Renewable Energy

Operated by the Alliance for Sustainable Energy, LLC

DOE/GO-102009-2887

July 2009
For more information contact:

EERE Information Center

1-877-EERE-INF (1-877-337-3463)

www.eere.energy.gov/informationcenter

Printed with a renewable-source ink on paper containing at least $50 \%$ wastepaper, including $10 \%$ post consumer waste. 